\title{
Epstein-Barr Virus (HHV-4) Inoculation to Rabbits by Intranasal and Oral Routes Results in Subacute and/or Persistent Infection Dissimilar to Human Disease
}

\author{
Julius Rajčáni ${ }^{a} \quad K^{2}$ lman Szenthe ${ }^{a}$ Vladimira Ďurmanováa Agnes Tóth $^{b}$ \\ Balazs Ásványi $^{b}$ Ervin Pitlik $^{a}$ Laszlo Stipkovits ${ }^{c}$ Susan Szathmary ${ }^{b}$ \\ ${ }^{a}$ Research Triangle Europe Research Center, ${ }^{b}$ Galenbio, and ${ }^{c}$ Carlsbad Research Organization, \\ Mosonmagyaróvár, Hungary
}

\section{Key Words}

Rabbit model $\cdot$ Epstein-Barr virus $\cdot$ Infection markers

\begin{abstract}
Objective: We report the infection of New Zealand white rabbits with Epstein-Barr virus (EBV). Methods: EBV prepared in B95-8 (producer) cells was inoculated to rabbits by combined intranasal and oral routes. Blood and white blood cell (WBC) samples were taken before infection, then on days 8,28 and 98 post-infection (p.i.). Results: Administration of either $3 \times 10^{8}$ (group $A, 11$ rabbits) or $1 \times 10^{9}$ (group $B, 10$ rabbits) EBV DNA copies per animal induced subacute and/or persistent infection. The IgG antibodies in plasma were detected by ELISA as well as by immunoblot (IB). The IB bands showed mainly antibodies to the BZRF1/Zta transactivation polypeptide (69.2\%), the p54 early protein (53.4\%) and to the p23 capsid protein (35.8\%). No anti-EBNA1 antibody was detected throughout. Viral DNA could be detected by PCR in WBCs and/or spleen of 7 out of 21 infected rabbits $(30 \%)$, while $60-80 \%$ of them showed serologic response. The transiently present EBV DNA was accompanied by LMP1 antigen. Conclusions: Rabbits developed persistent EBV infection in the absence of EBNA1 antibodies and
\end{abstract}

by the lack of typical infectious mononucleosis-like syndrome. The absence of EBNA1 antibody may reflect the lack of EBNA1 in B cells of EBV-inoculated rabbits.

(C) 2014 S. Karger AG, Base

\section{Introduction}

The great majority of animal models mimicking Epstein-Barr virus (EBV, HHV-4) infection are either animals with comprehensive housing demands (monkeys and/or SCID mice, i.e. mice with severe combined immunodeficiency disease) or animals inoculated with gammaherpesviruses distinct from the original virus [1]. Rabbits infected with EBV-related herpesviruses were examined by several authors [2-6]. These experiments mainly resulted in the establishment of lymphoproliferative disease and/or formation of malignant lymphomas. Inbred laboratory mice infected with the murid herpesvirus $(\mathrm{MuH}-4)$ provide an interesting model for infectious mononucleosis and/or lymphoid proliferation [7-10]. Newborn mice deficient for $\mathrm{Rag}_{2} / \gamma_{\mathrm{c}}$ lymphocytes were transplanted with human CD34 cord blood cells to establish a model for the interaction of EBV with naive B cells in order to follow

\section{KARGER}

E-Mail karger@karger.com

www.karger.com/int
(C) 2014 S. Karger AG, Basel

0300-5526/14/0575-0254\$39.50/0 
the corresponding reaction of CD4 and CD8 T cells [11]. A computer model, providing virtual environment to perform experiments not feasible in human volunteers, was also described [12]. Just recently, it has been shown that EBV can infect rabbit lymphocytes after intravenous inoculation [13]. Okuno et al. [14] described the infection of rabbits with EBV produced in B95-8 cells following intranasal or oral inoculations. Here we report our experience with the combined intranasal as well as oral inoculations of New Zealand white rabbits with two different virus doses as reflected by the DNA copy number within the virus inoculum. The aim was to present a useful and inexpensive animal model for testing the efficacy of a multipeptide microparticle-based EBV vaccine. We conclude that the value of individual tests for assessing the presence or absence of EBV infection in rabbits might be as follows (ordered from more reliable to less reliable signs): (1) antibodies as detected by IB $>$ (2) antibodies as detected by EA-D ELISA $>$ the single step or nested polymerase chain reaction (PCR) for EBV DNA detection in peripheral white blood cells (WBCs) and/or spleen $>$ detection of LMP1 antigen in WBC smears by indirect immunofluorescence (IF) test. These examinations were supplemented by less specific capsid antibody ELISA and finally by lymphocyte/monocyte counts in classical peripheral blood smears.

\section{Materials and Methods}

\section{Animals}

New Zealand white rabbits were housed under standard conditions. Blood was drawn before virus administration (interval 0), 8 and 28 days post-infection (p.i.) (intervals 1 and 2) and on the autopsy day (98 days p.i.). About 5-10 ml of blood (at autopsy always $10 \mathrm{ml}$ ) was drawn into isotonic EDTA/PBS solution to prevent clotting and layered (under sterile conditions) over the FicollPaque PLUS-t gradient (GE Healthcare, Life Sciences). The blood mixture was centrifuged (as recommended) to separate the serum from erythrocytes and WBCs. The separated WBCs were used for preparation of smears as well as for DNA extraction (described below). In addition, native blood smears were prepared directly from whole blood and air dried. The WBC smears were fixed either in methyl alcohol or in acetone for $10 \mathrm{~min}$ and stored at $-20^{\circ}$. The plasma (serum) samples obtained at each interval were examined by ELISA (for both capsid and EA-D antigens) and by immunoblot (IB) techniques (details described below). Before autopsy, the rabbits received a slight overdose of analgesic drug solution (T61) into the abdominal cavity. In deep anesthesia, about $10 \mathrm{ml}$ of blood was first drawn from the left heart chamber. Then both the abdominal as well as pleural cavities were opened and the spleen, liver, kidneys, thymus and lungs were removed. Pieces from liver, spleen and thymus were quickly frozen in liquid propane/butane and stored for DNA extraction (at $-76^{\circ}$ in a freezer). In addition, cube-shaped tissue blocks $(0.7 \times 0.8 \mathrm{~cm})$ were quickly frozen and stored on dry ice until cut in a cryostat. The cryostat sections were fixed in cold acetone for $10 \mathrm{~min}$ and stained by indirect IF method.

\section{EBV Preparation for Infection of Rabbits}

B95-8 cells were cultured in RPMI-1640 medium supplemented with $1 \%$ fresh glutamine (Gibco), 10\% fetal calf serum (Sigma) and antibiotics (penicillin $500 \mu \mathrm{g} / \mathrm{ml}$, streptomycin 80 $\mu \mathrm{g} / \mathrm{ml}$, both from Gibco). The number of seeded cells $\left(2 \times 10^{5} /\right.$ $\mathrm{ml}$ ) doubled within 4 days (reaching the concentration of up to $\left.5 \times 10^{5} / \mathrm{ml}\right)$ and tripled within 7 days $\left(>1 \times 10^{6} / \mathrm{ml}\right)$. The harvest from several bottles was collected to prepare a single large batch of $100-200 \mathrm{ml}$ volume. This suspension was repeatedly sedimented (gently at $900 \mathrm{~g}$ ) to obtain a small final volume of $1-2 \mathrm{ml}$ (100 times concentrated). At the first centrifugation, 1 million cells were taken for DNA extraction and a similar amount was removed for morphological examinations. Then the 100 times concentrated B95-8 cell suspension (containing $10^{7}$ cells $/ 0.1 \mathrm{ml}$ ) was frozen and thawed 3 times (in a water bath at $37^{\circ}$ ) and stored (at $-80^{\circ}$ ) until use. The contents of EBV DNA in the stocks used to infect rabbits (table 1 ) varied from $3 \times 10^{8}$ to $10^{9}$ DNA copies per animal ( 3 times $50 \mu$ l volume was inoculated into both nostrils and the mouth cavity).

\section{Serum Antibody Testing by ELISA}

The frozen $\left(-20^{\circ}\right)$ plasma (serum) samples from each interval (4 samples per rabbit) were examined for antibodies to EBV viral capsid antigen (VCA) using the commercial anti-human Captia EBV VCA IgG kit (Trinity Biotech) as well as for antibodies to EBV EA-D (early non-structural protein) using the commercial anti-human Captia EBV EA-D IgG kit (Trinity Biotech). In the former, the wells were coated with a recombinant fusion protein coming from C-terminal 53 aa polypeptide fragment of the p18 (BFRF3) protein and the $23 \mathrm{kDa}$ (p23/BLRF2) capsid polypeptide, which represents an EBV-specific capsid component [15, 16]. For EA-D antibody the recombinant early antigen p54 polypeptide (BMRF1), a DNA polymerase cofactor, had been coated to the wells [17]. The rabbit plasma (serum) samples were diluted as recommended (at a proportion of 1:20 using the diluent provided). To achieve higher reading precision, additional serum dilutions (regularly 1:40, 1:80, 1:160 and occasionally even up to 1:1,280) were prepared and added to individual wells. The samples were incubated for $30 \mathrm{~min}$ at room temperature. The second antibody for the detection of IgG bound from rabbit serum was anti-rabbit $(\mathrm{H}+\mathrm{L}) / \mathrm{HRP}$-labelled conjugate (Millipore) in dilution 1:3,000, which was incubated for $30 \mathrm{~min}$ at room temperature. For each plate, 2 positive (human) controls, 1 negative (human) control as well as the blank reagent (provided by the kit) were included and allowed to react with anti-human/HRP antibody provided by the manufacturer. The blank solution was also used in combination with the anti-rabbit HRP-labelled conjugate. Reading was performed at $450 \mathrm{~nm}$ against the blank reagent using an ELISA reader (ASYS). The positive reaction was read according to the immune status ratio (ISR) cut-off value (higher than 1.1 was regarded for positive). The ISR value was calculated using the formula $\mathrm{S} /[(\mathrm{CO} 1+\mathrm{CO} 2+\mathrm{CO} 3) / 3] \times \mathrm{CF}$ in which $\mathrm{CO}$ is the $\mathrm{OD}$ value obtained by calibrator, the correction factor $(\mathrm{CF})$ was provided by the kit, and $\mathrm{S}$ is the OD obtained for the tested serum samples. The results as shown in graphs were expressed in terms of the highest dilution (when the ISR was positive) or the lowest dilution (when ISR was negative). 
Table 1. DNA measurements of EBV DNA copy number by RT-PCR

\begin{tabular}{lllll}
\hline $\begin{array}{l}\text { Cell preparation date } \\
\text { and stock No. }\end{array}$ & $\begin{array}{l}\text { Measurement } \\
\text { date }\end{array}$ & $\begin{array}{l}\text { Cell counts in } \\
\text { culture }\end{array}$ & $\begin{array}{l}\text { Cell count at DNA } \\
\text { extraction/elution } \\
\text { volume }\end{array}$ & $\begin{array}{l}\text { DNA concentration DNA copy } \\
\text { and elution volume } \\
\text { number* } \\
\text { per cell }\end{array}$ \\
\hline $\begin{array}{l}\text { February 24, 2011 } \\
\begin{array}{l}\text { Stock 1 } \\
\text { for calibration)** }\end{array}\end{array}$ & March 1, 2011 & $\begin{array}{l}4.5 \times 10^{4} / \mathrm{ml} ; 8 \times 10^{5} / \mathrm{flask} \\
\text { (total 3 flasks) }\end{array}$ & $1 \times 10^{6} / 200 \mu \mathrm{l}^{* *}$ & $\begin{array}{l}197 \mathrm{ng} / \mu \mathrm{l} \\
200 \mu \mathrm{l}\end{array}$ \\
\hline $\begin{array}{l}\text { November 7, 2011 } \\
\text { Stock 2 }\end{array}$ & November 14, 2011 & $\begin{array}{l}3.5 \times 10^{5} / \mathrm{ml} \text {; a total } \\
\text { of } 1.08 \times 10^{8} \text { cells }\end{array}$ & $7 \times 10^{5} / 100 \mu \mathrm{l}$ & $\begin{array}{l}65 \mathrm{ng} / \mu \mathrm{l} \\
100 \mu \mathrm{l}\end{array}$ \\
\hline $\begin{array}{l}\text { January 3, 2012 } \\
\text { Stock 3 }\end{array}$ & January 21, 2012 & $\begin{array}{l}2.5 \times 10^{5} / \mathrm{ml} \text { a total } \\
\text { of } 6.4 \times 10^{7} \text { cells }\end{array}$ & $1 \times 10^{6} / 150 \mu \mathrm{l}$ & $\begin{array}{l}211 \mathrm{ng} / \mu \mathrm{l} \\
150 \mu \mathrm{l}\end{array}$ \\
\hline
\end{tabular}

* BALF1 and/or LMP1 primers were used in two independently repeated measurements.

** The standard stock 1 for DNA calibration was measured in a different laboratory (using DNA polymerase primers).

\section{Serum Antibody Testing by Western Blot}

For Western blot (immunoblot, IB) the commercial recomLine EBV IgG kit (Microgen) was used. This kit provides the detection of 6 recombinant polypeptides bound to the nylon strip (EBNA1, p18, p23, Zta/BZLF1, p54 and p138). The strips were handled and serum stained as recommended by the manufacturer. Briefly, the strips were first immersed into the dilution reagent provided by the kit. Then $40 \mu \mathrm{l}$ of each rabbit serum (samples were from two intervals, i.e. days 28 and/or 98 p.i.) was added to achieve the final dilution of 1:50. After $60 \mathrm{~min}$ incubation, the strips were thoroughly washed using the wash reagent, and then goat anti-rabbit/ HRP (horseradish peroxidase labelled) antibody was added in the dilution of 1:200. After incubation for $30 \mathrm{~min}$, repeated washing followed in order to remove the unbound conjugated antibodies. Finally, the strips were treated with the visualization reagent (TMB) provided by the kit. After a 15-min incubation, the strips were washed with distilled water and dried. The stained strips were scanned and stored for documentation purposes. Reading of the results was made by comparison to the prototype control bands provided by the kit. The description of the intensity of individual bands was made according to the recommendations of the manufacturer (Microgen Line Assay) [16].

\section{Isolation of White Blood Cells}

Blood samples (minimal $5 \mathrm{ml}$, but maximal $10 \mathrm{ml}$ ) at any interval were drawn from the ear vein (at autopsy from the heart) and collected into blood clot-preventing tubes (containing $0.5 \%$ EDTA, ethylenediaminetetraacetic acid). The tubes were repeatedly inverted before further handling. From each blood sample, 2.5- or 3-ml aliquots were layered over an equal volume of FicollPaque PLUS-t solution and centrifuged at $900 \mathrm{~g}$ for $30 \mathrm{~min}$. The supernatant plasma was carefully removed not to disturb the WBCs containing the ring-shaped buffy coat zone in between the plasma and erythrocyte layers. The buffy coat zone was then carefully harvested and resuspended with sterile phosphate-buffered saline (PBS) to restore the original volume. The washed WBCs were concentrated by centrifugation (for $5 \mathrm{~min}$ at $950 \mathrm{~g}$ ) and resuspended in $1 \mathrm{ml}$ PBS, transferred into a $1.5-\mathrm{ml}$ Eppendorf tube and repeatedly centrifuged (for $2 \mathrm{~min}$ at $900 \mathrm{~g}$ ). The final sediment was resuspended in a small volume $(0.1$ or $0.2 \mathrm{ml})$ of PBS. The isolated WBCs were divided into two parts. About two times of 10 $\mu \mathrm{l}$ suspension was used for preparing two blood smears (for Giemsa and IF staining); the rest was frozen at $-76^{\circ}$ for DNA extraction procedures.

\section{Extraction of EBV DNA}

The two different methods described below were used to isolate the DNA either from the B95-8 cell cultures or from WBC and spleen tissue samples.

Procedure Used for QuickGene DNA Tissue Kit S (FujiFilm)

The cell sediment (from $1 \times 10^{6}$ B95-8 cells) was treated with $0.2 \mathrm{ml}$ proteinase $\mathrm{K}$ in tissue lysis buffer solution (as recommended by the manufacturer) for $60 \mathrm{~min}$ at $55^{\circ}$. The lysate was sedimented at $8,000 \mathrm{~g}$ for $3 \mathrm{~min}$, dissolved in $180 \mu \mathrm{l}$ of the lysis buffer, vortexed and after incubation at $56^{\circ}$ for $10 \mathrm{~min}$, cooled on ice. Then $240 \mu \mathrm{l}$ of absolute ethanol (p.a.) was added and vortexed. Finally, the clarified lysate was applied to the cartridge provided by the kit. After adsorption, the cartridge was repeatedly washed with $750 \mu \mathrm{l}$ of wash buffer provided by the kit taking advantage of the pressurization procedure using the Quick-Gene Mini80 workflow machine (FujiFilm). When the cartridge was turned into elution position, the DNA was eluted into 100 or $200 \mu \mathrm{l}$ elution buffer provided by the kit. The concentration of the DNA within the eluted sample was measured by a spectrophotometer NanoDrop 2000c (ThermoScientific) in a volume of $1 \mu \mathrm{l}$. The concentration of the total eluted DNA (obtained from $1 \times 10^{6} \mathrm{EBV}$ producer cells into the volume of 100-200 $\mu \mathrm{l}$ ) ranged from 59 to $382 \mathrm{ng} / \mu \mathrm{l}$. The DNA samples prepared from individual virus stocks were stored at $-20^{\circ}$.

\section{Procedure Used for Blood and Tissue Samples (DNeasy}

Isolation Kit, Qiagen)

Briefly, the following protocol was applied for the B95-8 cell culture: (1) Centrifugation of $1 \times 10^{6}$ cells for $5 \mathrm{~min}$ at $1,600 \mathrm{~g}$ and resuspending the pellet into $200 \mu \mathrm{l}$ PBS. (2) Adding $20 \mu \mathrm{l}$ of proteinase K; vortexing and diluting in $200 \mu$ l ATL buffer (provided 
by the kit). (3) The sample was deproteinized at $56^{\circ}$ for $10 \mathrm{~min}$ and then $200 \mu$ l absolute ethanol (p.a.) was added. (4) Then the sample was transferred to the spin column, centrifuged at 8,000 rpm for $1 \mathrm{~min}$ and the flow-through discarded. (5) Thereafter, $500 \mu \mathrm{l}$ AW1 buffer (provided by the kit) was added and again centrifuged at $8,000 \mathrm{rpm}$ for $1 \mathrm{~min}$ and the flow-through discarded. (6) Next, $500 \mu \mathrm{l}$ AW2 buffer was added and the DNA was centrifuged at 13,000 rpm for $3 \mathrm{~min}$; flow-through discarded. (7) Finally, the spin column was placed on a $1.5-\mathrm{ml}$ tube and $100 \mu \mathrm{l}$ AE buffer was added. After $10 \mathrm{~min}$ incubation and centrifugation had followed at $8,000 \mathrm{rpm}$ for $1 \mathrm{~min}$, the eluted DNA was collected and stored as mentioned above. Spleen tissue samples were treated using some alternative modifications. The procedure started from $25 \mathrm{mg}$ tissue cut (trimmed) into small pieces, which were placed in a $1.5-\mathrm{ml}$ microcentrifuge tube. $180 \mu \mathrm{l}$ ATL buffer was then added to homogenize the tissue fragments and incubated for $3 \mathrm{~h}$. This procedure was also used for extraction of EBV DNA from isolated WBCs.

\section{Classical and Nested Polymerase Chain Reaction}

The classical single round PCR amplification reaction was done to detect the EBV DNA in the WBC and spleen tissue DNA extracts. PCR primers for the single round PCR assay amplified the LMP1 gene sequence: (1) LMP1pU (forward primer 1, $169,724-169,741$, also used for the nested procedure as primer 1B): $5^{\prime}$-ggg caa gct gtg gga atg- $3^{\prime}$ and (2) LMP1pL (reversed primer 2, $169,911-169,892$, also used for nested procedure as primer $2 \mathrm{~B}$ ): $5^{\prime}$ ctc acc tga acc ccc cta aa-3' [18], with the product length $187 \mathrm{bp}$. The FastStartTaq DNA polymerase (Roche) kit was used as follows: the total $50-\mu \mathrm{l}$ volume Master Mix (for 1 sample) consisted of $1 \mu \mathrm{ldNTP}$ (a mix provided by the kit), $5 \mu \mathrm{l}$ of $2 \mathrm{mmol} \mathrm{MgCl}_{2} 5$ $\mu \mathrm{l}$ of $10 \times$ buffer (provided by the kit), $2 \mu \mathrm{l}$ of forward and $2 \mu \mathrm{l}$ of reversed primers 1 and $2(5 \mathrm{pmol}), 1 \mu \mathrm{l}$ of DNA sample, $0.5 \mu \mathrm{l}$ of Taq polymerase and $33.5 \mu$ l of distilled water (ultrapure). The reaction conditions for the Applied Biosystems GeneAmp 2700 Thermal Cycler were the following: initial denaturing at $95^{\circ}$ for $3 \mathrm{~min}$, then 40 cycles as follows: denaturing at $95^{\circ}$ for $40 \mathrm{~s}$, annealing at $55^{\circ}$ for $40 \mathrm{~s}$, and elongation at $72^{\circ}$ for $1 \mathrm{~min}$. The final extension was allowed to proceed at $72^{\circ}$ for $3 \mathrm{~min}$. All the DNA samples were amplified by the above-described single PCR assay. The PCR products were analyzed in agarose electrophoresis $(1 \times$ TAE buffer system). The positive and/or possibly (weakly) positive samples were retested using the nested PCR procedure. For the nested assay the following primers were used: LMP1KU1 (outer forward primer $1 \mathrm{~A}$ ): $5^{\prime}$-ctc att ctg aaa ttc cca tat $\mathrm{cc}-3^{\prime}$ and LMP1KL1 (outer reversed primer $2 \mathrm{~A}$ ): $5^{\prime}$-gca gtg tga gag agg ctt atg tag g- $3^{\prime}$, with the product length $485 \mathrm{bp}$. For second amplification (with the inner primer-set $1 \mathrm{~B}$ and $2 \mathrm{~B}$ ) we have taken $1 \mu \mathrm{l}$ from each of $50 \times$ diluted first amplified sample (run with the outer primers $1 \mathrm{~A}$ and $2 \mathrm{~A}$ ). The same reaction conditions were used for the nested PCR as for the single PCR, except that the cycle numbers, which were 40 for the outer and 35 for the inner reactions, respectively (i.e. 75 cycles were run together at both subsequent amplification procedures). Other modifications were: denaturing at $95^{\circ}$ for $5 \mathrm{~min}$ and before second cycling, at running the cycles at second amplification, the denaturing was performed at $95^{\circ}$ for $40 \mathrm{~s}$, the annealing proceeded at $60^{\circ}$ for $40 \mathrm{~s}$ and the elongation followed at $72^{\circ}$ for $1 \mathrm{~min}$. The final extension at the second cycling was performed at $72^{\circ}$ for $8 \mathrm{~min}$. The water control from the first amplification procedure was repeatedly amplified to exclude a false positive nested reaction.
EBV DNA Copy Number Determination by Real-Time PCR in the B95-8 Cell Extracts

Two different approaches with different primers were used for estimation of EBV DNA copy number in the producer B95-8 cells.

SYBR Green-Based Real-Time PCR Using LMP1 Primers

The SYBR green-based real-time (RT) PCR reaction was run using the reagents from the Maxima SYBR green Rox kit (Fermentas), which contains the qPCR Master Mix $(2 \times)$ suitable for the RT cycler Roche (2.0 LightCycler $\left.{ }^{\circledR}\right)$. The composition of the reaction mix varied according to the different Master Mix volumes, $25 \mu \mathrm{l}$ and/or $10 \mu \mathrm{l}$, respectively. For $25 \mu \mathrm{l}$ volume the qPCR mix contained $12.5 \mu \mathrm{l}$ of Master Mix, $2.5 \mu \mathrm{l}$ of each 10-pmol primers designated as LMP1pU and LMP2pU (described above, flank a 169bp fragment from the LMP1 ORF), $1 \mu$ of the DNA sample and L6.5 $\mu \mathrm{l}$ nuclease-free water (a total $25 \mu \mathrm{l}$ ). For the lower volume (Master Mix II) of qPCR mix, $5 \mu$ of Master Mix, $0.5 \mu$ of each primer, L1 $\mu \mathrm{l}$ of measured sample, and $3 \mu \mathrm{l}$ of water were taken (total of $10 \mu \mathrm{l}$ ). The cycling conditions were the following: denaturing in the beginning at $95^{\circ}$ for $10 \mathrm{~min}$, cycling comprised denaturing at $95^{\circ}$ for $15 \mathrm{~s}$, then annealing at $60^{\circ}$ for $40 \mathrm{~s}$, and elongation at $72^{\circ}$ for $10 \mathrm{~s}$. Together, 40 cycles were applied. The last elongation time had been prolonged to $60 \mathrm{~s}$. The DNA samples were measured in at least three 10 -fold decreasing concentrations, namely diluted $10 \times, 100 \times$ and/or $1,000 \times$. Positive and negative controls were included such as: (1) the B95-8 standard (independently measured in the Reference Herpesvirus Laboratory of the Hungarian National Epidemiologic Centre in Budapest using the DNA polymerase primers and a different equipment); (2) the DNA as prepared from one of the three stocks (table 1); (3) the DNA from the non-producer BL-41 cell line representing the low DNA concentration control, and (4) negative water control. Occasionally, additional control cell line DNA samples (such as Akata) were included.

LightCycler 480 Probes Master for Roche LightCycler 480 Using BALF5 Probe and Primer Sets

The LightCycler 480 Probes Master kit has been used, which was designed for RT-PCR using the LightCycler 480 instrument in combination with suitable probes (e.g. hydrolysis probes, Universal ProbeLibrary probes, and others) and gene-specific primers. We used the hydrolysis probe against the BALF5 ORF (EBV DNA polymerase) to determine the real copy number of a DNApositive independent standard defined earlier through the TIB MolBio EBV copy number LightMix detection kit (kindly performed by Dr. Marta Csire at the National Human Herpesvirus Laboratory Unit, Budapest). The kit provides LightCycler 480 Probes Master Mix ( $2 \times$ concentrated) and $\mathrm{H}_{2} \mathrm{O}$ (PCR-grade). We used $5 \mu \mathrm{l}$ Master and $2 \mu \mathrm{l}$ water with $1 \mu \mathrm{l}$ of each primer $(5 \mathrm{pmol} /$ $\mu \mathrm{l})$; the probe was added in $2 \mathrm{pmol} / \mu \mathrm{l}$ concentration and then 1 $\mu \mathrm{l}$ template to a final volume of $10 \mu \mathrm{l}$. The sequence of primers and probe were as follows: (1) BALF5 forward (ups): $5^{\prime}$-cgg aag ccc tct gga ctt c- $3^{\prime}$; (2) BALF5 reversed (dns): $5^{\prime}$-ccc tgt tta tcc gat gga atg- $3^{\prime}$, and (3) BALF5 Probe OK: 5'-/56-FAM/-tgt aca cgc ac gaga at gc-BHQ- $3^{\prime}$. The cycling conditions were the following: denaturing in the beginning at $95^{\circ}$ for $5 \mathrm{~min}$, cycling comprised denaturing at $\left(95^{\circ}\right)$ for $10 \mathrm{~s}$, then annealing at $62^{\circ}$ for $40 \mathrm{~s}$, and elongation at $72^{\circ}$ for $1 \mathrm{~s}$. Together, 40 cycles were applied. 
Testing the EBV Capsid Antigen in B95-8 Cells by

Immunofluorescence

A proportion of the cell suspension (see above: EBV Preparation for Infection of Rabbits) was dropped into the wells ( $10^{5}$ cells/ well/10 $\mu \mathrm{l}$ ) of the 8 -well microscope slide (Menze-Gläser), dried, fixed with acetone for $10 \mathrm{~min}$ and stored for indirect $\mathrm{F}$ staining. Alternatively, the rest of the suspension was dropped onto the wells of poly-L-lysine (Sigma-Aldrich) pretreated and sterilized slides, fixed in acetone and stored frozen for the in situ hybridization procedure (to detect the EBER transcripts, see below). The capsid antigen in producer cells was checked as compared to BL-41 non-producer cells using monoclonal anti-VCA antibody (mouse anti-EBV/VCA-gp125; Chemicon/Millipore). After treatment with the anti-VCA antibody for $40 \mathrm{~min}$ (at dilution $1 \mu \mathrm{g} / \mathrm{ml}$ ), the slides were washed in PBS (3 times) and then treated with antimouse FITC-conjugated antibody (goat anti-mouse/FITC; Millipore) for $30 \mathrm{~min}$ at a concentration of $10 \mu \mathrm{g} / \mathrm{ml}$. After removal of the conjugate, the slides were washed 3 times in PBS $(3 \times 10 \mathrm{~min})$ and mounted into aqueous permanent 'Ultramount' medium (Dako). The slides were examined and photographed in the Zeiss AxioObserver D1 inverted microscope equipped with the $\mathrm{HBO}$ 100 illuminating system and the AxiCamMRm camera with the corresponding software (Axiovision Rel.4.8).

\section{Detection of EBER Transcripts in B95-8 Cells by in situ}

Hybridization

The EBER molecules were detected by in situ hybridization kit (Dako, PNA ISH kit). The cells (B95-8, BL-41 and Akata) fixed under RNase activity-free conditions (see above) were handled as recommended by the manufacturer. Briefly, they were deproteinized (for $20 \mathrm{~min}$ ) with diluted $(1: 100)$ proteinase $\mathrm{K}$ (in the TBS buffer provided), then one of the hapten 5-carboxy-fluoresceinconjugated peptide nucleic acid (PNA) probes was added and allowed to hybridize for $90 \mathrm{~min}$ at $55^{\circ}$ in a humid chamber. The positive and negative PNA control probes were provided by the kit, the specific EBER PNA probe (for EBER detection) was purchased separately (Dako). Following hybridization with either probe (as a rule $3 \times 2$ wells were treated as described, additional controls were handled omitting any probe), the cells were washed under stringent conditions with the diluted wash solution provided by the kit (for $25 \mathrm{~min}$ at $55^{\circ}$ ). Thereafter, the anti-FITC/AP antibody was added and incubated for $30 \mathrm{~min}$. Finally, after washing as recommended, the cells were handled with the substrate solution (for 40 $\min$ ) to visualize the peroxidase, counterstained with hematoxylin and mounted into Paramount medium.

\section{Staining of Smears from Isolated WBCs and/or the Whole} Blood

The acetone-fixed WBC smears were stained by indirect IF for LMP1 (latent membrane protein 1) using specific monoclonal antibody (Dako). The monoclonal anti-LMP1 antibody was also used to stain the spleen and/or thymus cryostat sections (fixed in acetone). The anti-LMP1 antibody was used at dilution 1:200 (applied at room temperature $37^{\circ}$ for $\left.40 \mathrm{~min}\right)$. After 3 washes in PBS ( $3 \times$ $10 \mathrm{~min})$, the slides were overlaid with the donkey anti-mouse/ FITC conjugate (Jackson ImmunoResearch) diluted 1:200 (incubated at room temperature for $30 \mathrm{~min}$ ). Finally, the slides were washed in tap water and mounted into Ultramount permanent medium. To avoid non-specific staining, the conjugate was adsorbed to a suspension of the BL-41 non-producer cells $\left(5 \times 10^{6} /\right.$ $\mathrm{ml}$ ) for $30 \mathrm{~min}$ at $37^{\circ}$. Producer as well as non-producer cell smears were occasionally stained along with the WBC smears as positive and/or negative controls. To assess the interaction of the conjugate with spleen sections, parallel sections were treated with the conjugate only (no LMP1 antibody).

The methanol-fixed slides were first treated with the MayGrünwald solution for 5 min then with the Giemsa-Romanowski solution (diluted 1:10) for $20 \mathrm{~min}$. After rinsing in distilled water, the slides were differentiated using acidified distilled water (14 drops acetic acid into $120 \mathrm{ml}$ water). Finally, the slides were mounted into a permanent medium.

Whole blood smears were prepared on clean (alcohol-ether treated) microscopic slides. The blood sample was dropped on the slide close to its edge. Then with the help of another slide put at a $45^{\circ}$ angle behind the drop, the blood was stretched over the slide kept in a strictly horizontal position, allowed to dry and afterwards either stored in a proper box or stained immediately. At staining, the slides were immersed for $10 \mathrm{~s}$ into the Dia-Fix Panoptic solution in a glass jar. The rest of the fixative was sucked off using a filter paper and the slides were repeatedly air dried, immersed into the Dia-Blue Panoptic staining solution for 10-20 s and cleaned by sucking off the rest of the dye. Finally, the slides were rinsed in distilled water and air dried. The results were read in a light microscope using $100 \times$ objective magnification in combination with immersion oil.

\section{Results}

\section{Detection and Quantification of EBV DNA in the \\ B95-8 Cell Suspensions Used for Inoculation of \\ Rabbits}

The proportion of B95-8 cells expressing the EBV capsid antigen (as detected by IF) varied at different passage levels. In contrast, an overwhelming majority of B95-8 cells (up most 100\%) revealed the presence of EBER molecules by hybridization in situ. This indicates that the proportion of virus producer cells in comparison to the EBV DNA carrier cells ranged from 5 to $10 \%$ at different passage levels. To calculate the copy number of inoculated viral DNA within the administered volume of cell suspension more precisely, a standard virus stock (No. 1 in table 1) was prepared. This stock was later on used for comparative measurements accomplished in two independent laboratories (table 1). The DNA copy number in the virus stocks 2 and 3 , which were prepared for infection of rabbits in experiments $\mathrm{A}$ and $\mathrm{B}$, was measured at the same passage level, when the corresponding largescale (concentrated) B95-8 cell suspension was prepared (see Materials and Methods for details). The final volume of concentrated stock 2 was $2 \mathrm{ml}$, in which the total estimated DNA copy number was $2.48 \times 10^{10}$, an amount which corresponded to an estimated number of $1 \times 10^{9}$ capsid antigen-producing cells. By stock 2 (in experiment 
Fig. 1. IgG antibody responses to EBV capsid antigen in group A (a) rabbits infected with the lower EBV dose $\left(3-4 \times 10^{8}\right.$ DNA copy in $150 \mu \mathrm{l}$ ) and in group B animals $(\mathbf{b}, \mathbf{c})$ inoculated with the higher EBV dose $\left(1 \times 10^{9}\right.$ DNA copies in $\left.150 \mu \mathrm{l}\right)$. Sera from group $\mathrm{B}$ showed a false positive binding (ISR $>1.1$ at dilutions 1:20 or even 1:40) before virus administration (designated interval $\left.0^{*}, \mathbf{b}\right)$. Therefore, a positive capsid antibody response was registered in rabbits $\mathrm{K} 2$, K3, K13, K18, K21 and K23 only (better visible after subtraction of pre-infection interval values as shown in $\mathbf{c}$ ).
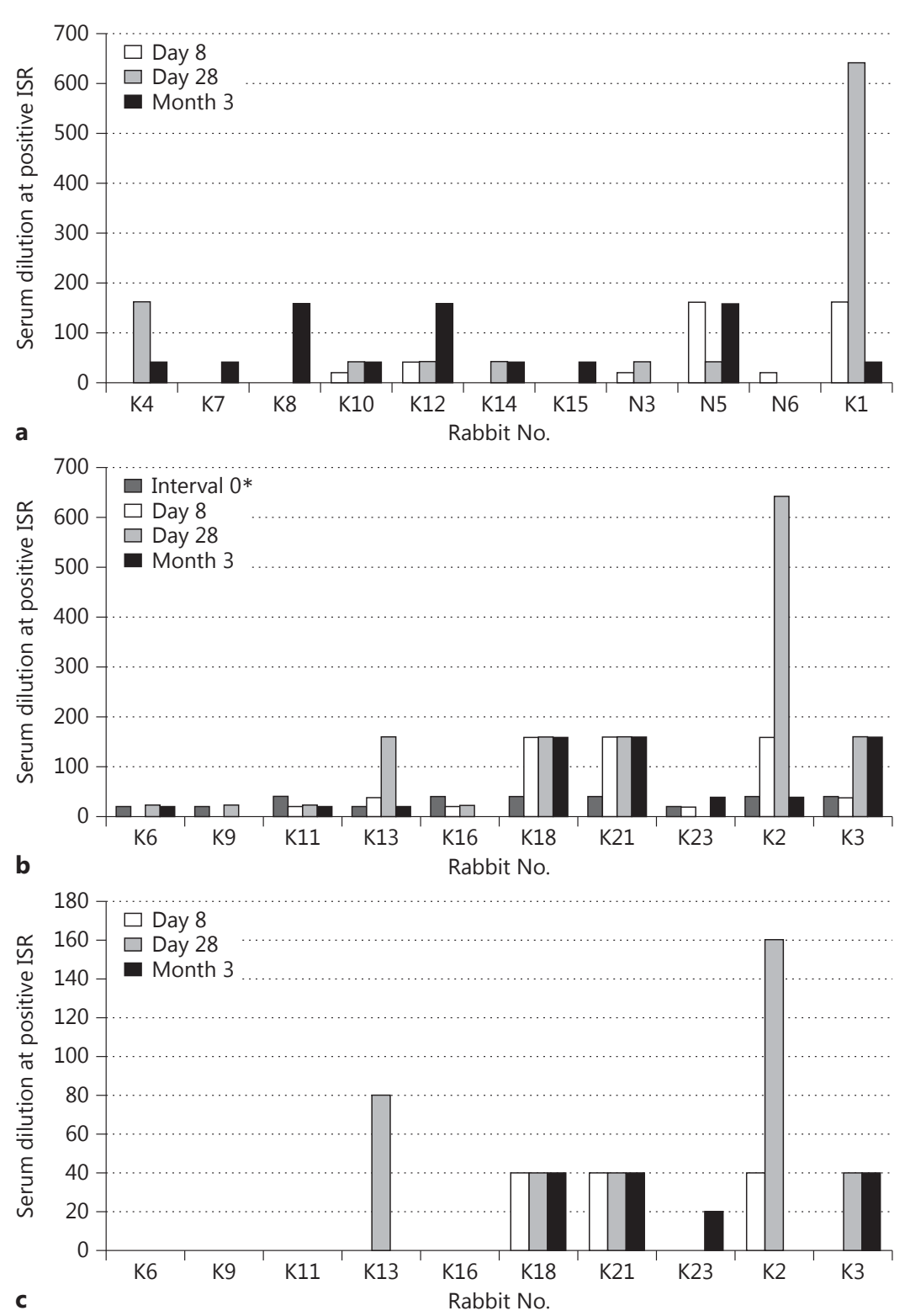

A) the real DNA copy number administered per animal (a total volume of $150 \mu \mathrm{l}$ per animal) might be less than expected, i.e. it corresponded to a minimum of $3-4 \times 10^{8}$ copies only, because repeated DNA measurements in the rest of administered material showed as few as $50 \mathrm{DNA}$ copies per cell. The reason for such discrepancy might be that during preparation of concentrated cell homogenate (by freezing and thawing of B95-8 cells), the DNA copy number has decreased more than 2-fold. For stock 3, which had a total volume of $1.6 \mathrm{ml}$, the estimated copy number measured was $1.34 \times 10^{10}$, which corresponded to approximately $6.7 \times 10^{8}$ capsid antigen-expressing cells. To avoid the changes in copy number by additional manipulation, the B95-8 cells for experiment B were disrupted using an ultrasound sonicator. In this second experiment (B), the estimated EBV DNA copy number administered within the $150-\mu \mathrm{l}$ dose corresponded to the expected amount of $1 \times 10^{9}$ DNA copies per animal. Nevertheless, the real infectious EBV dose present in either virus stock was not determined. 
Fig. 2. IgG antibody response to the nonstructural (early) antigen (EA-D) in group $A(\mathbf{a})$ and group $B(\mathbf{b})$ rabbits. With the exception of rabbit K4 (group A, interval $0^{*}$ ), no false positive binding occurred with the pre-infection sera when tested on EA-Dcoated microplates. There was no early antibody response by day 8 in group A rabbits (a). The early IgG antibody levels correlated well with the higher virus dose administered to group B animals (b).

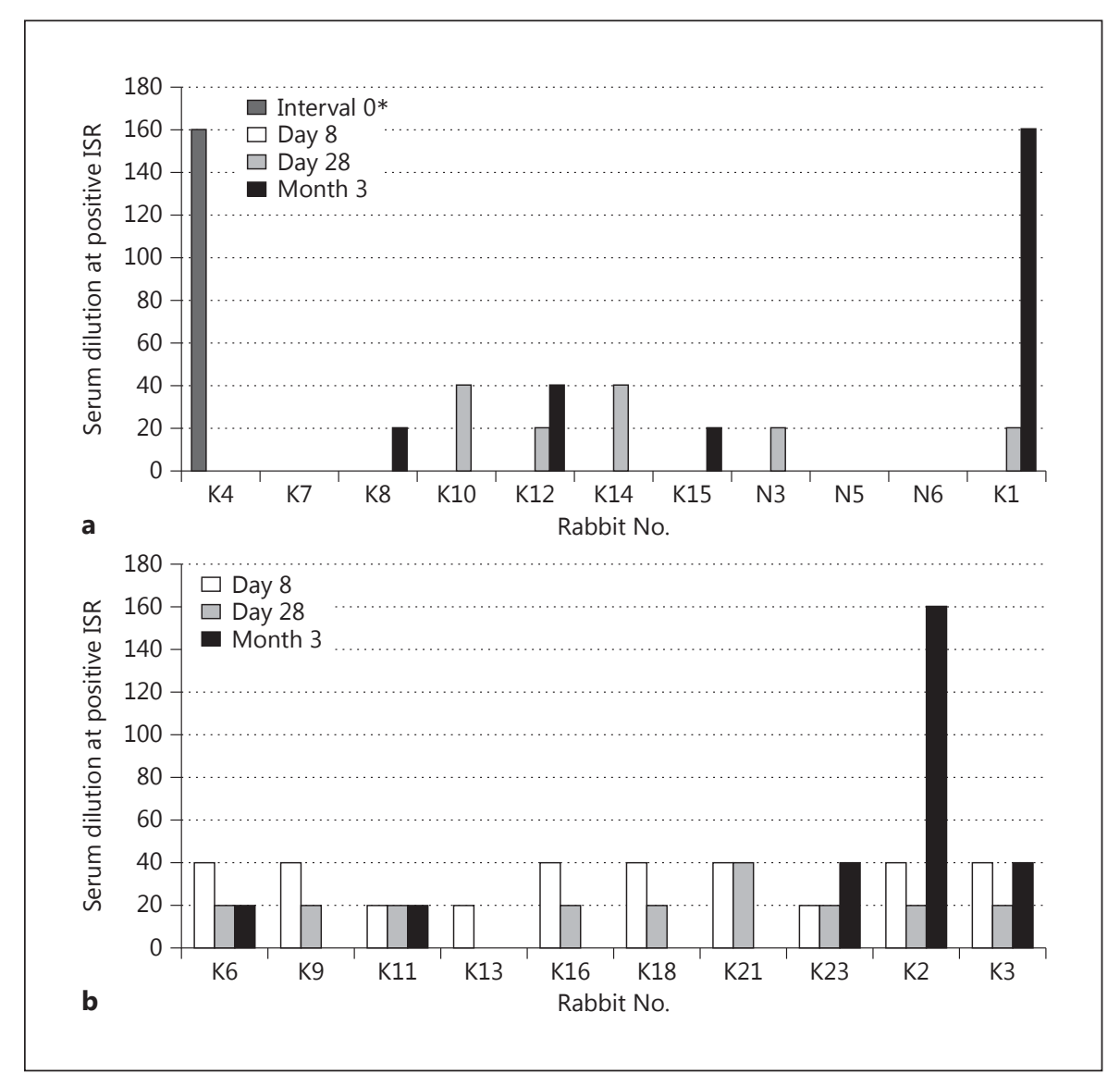

\section{Serological Results as Detected by ELISA}

The sera of EBV-infected rabbits were tested against two antigens, namely the capsid antigen (VCAp23) and the non-structural early antigen (EA-D/p54). About the half of sera coming from the interval before virus administration (interval 0) showed an elevated background level of binding to capsid antigen (VCA) at dilutions 1:20 and/or 1:40. Therefore, the animals were divided into two groups, designated A (K1, K4, K7, K8, K10, K12, K14, K15, N3, N4 and N5) and B (K2, K3, K6, K9, K11, K13, $\mathrm{K} 16, \mathrm{~K} 18, \mathrm{~K} 21$ and K23). Group A consisted of rabbits in which pre-infection sera showed no false positive binding to the VCA-coated microplates, while group B pre-infection sera did. As seen in figure 1a, in group A rabbits which had been infected with the lower EBV dose (3-4 $\times$ $10^{8} \mathrm{DNA}$ copy in $150 \mu \mathrm{l}$ ) five sera were positive (K1, K10, K12, N3 and N5) already by day 8 (45.5\%). Later on, by day 28 , six sera were found positive and by day 98 , the anti-VCA reactivity was found in 9 out of 11 samples (81.2\%). Figure 1a also shows that only 4 out of 10 infected animals revealed a positive response in all post-infec- tion intervals tested. Only 1 animal (K12) responded as theoretically expected, i.e. with an anti-VCA IgG response increasing by time and peaking on the last interval. The rabbit K1 developed an extremely high intensity reaction by day 98 .

The interpretation of the VCA antibody response in group $\mathrm{B}$ rabbits was more difficult due to the elevated background binding occurring in their pre-infection serum samples. As indicated in figure $1 \mathrm{~b}$, in 4 out of $10 \mathrm{rab}-$ bits (K6, K9, K11 and K16) no clear-cut antibody response can be seen despite of the higher EBV dose $(1 \times$ $10^{9}$ DNA copies in $150 \mu \mathrm{l}$ ) administered. To determine the positive anti-VCA score of any post-infection serum in the group B rabbits, the dilution of pre-infection serum which yielded a false positive ISR was subtracted from that of corresponding post-infection dilution value. For example, when a pre-infection rabbit serum showed ISR $>1.1$ at dilution 1:20 and/or 1:40, while the corresponding post-infection serum showed positive ISR $(>1.1)$ at dilution 1:160, we declared this serum for anti-capsid antibody-positive either at dilution of 1:80 or 1:40, respec- 
Table 2. Survey of IB results in comparison with ELISA serology

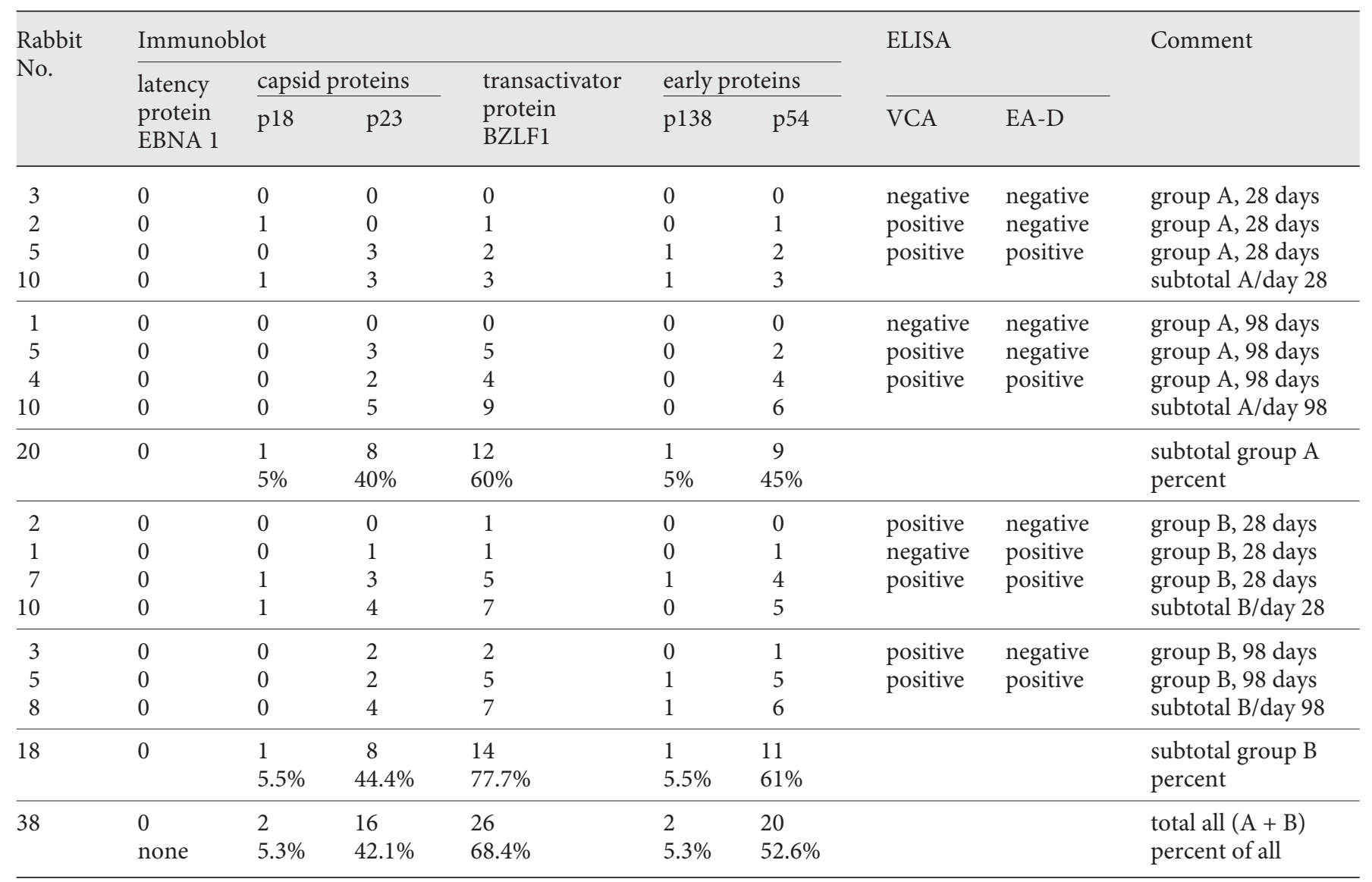

tively (fig. 1c). In two group B sera, Nos. K2 and K13, the highest ISR values were noticed at 28 days p.i., while another three sera showed an equally high antibody response at all the three intervals p.i. (K3, K18, K21). The above-mentioned four sera (K6, K9, K11 and K16) do not show any positive response.

In contrast to VCA-coated microplates, the EA-Dcoated ones did not bind any pre-infection interval rabbit sera in a non-specific manner (with the exception of the sample coming from rabbit K4). The early antibody formation demonstrated in figure $2 \mathrm{a}$ and $\mathrm{b}$ corresponded better to the EBV dose administered. The frequency of EA-D antibodies was lower in the group A rabbits which received the lower EBV dose (fig. 3a). In these, no early antibodies were seen on day 8 , but later on 7 out 11 animals developed a positive EA-D response. In contrast, in group B rabbits (fig. $2 \mathrm{~b}$ ) which were given the higher EBV dose the EA-D response was more frequent. All of the group B animals developed anti-EA-D antibodies at day
8 p.i. and 8 of them had antibodies on day 28 and 5 of them still revealed EA-D antibodies at 3 months p.i. For better results, the ELISA measurements for EA-D antibodies have been recommended as a reliable criterion of acute and/or recent EBV infection.

\section{Serological Results Detected by IB}

Overall, the group B sera showed more antibodies reacting with individual polypeptide bands as did the group A sera. Also the intensity of the serum antibody reaction with the antigens in individual strips has increased by time, i.e. a shift to more intensive bands was noted from day 28 to day 98 p.i. (fig. 3a, b). At least 7 paired samples showed conversion from negative to positive reaction (strips $\mathrm{K} 2 / 2$ vs. $\mathrm{K} 2 / 3$, $\mathrm{K} 3 / 2$ vs. $\mathrm{K} 3 / 3$, K6/2 vs. $\mathrm{K} 6 / 3$ in the group $B$ and $K 8 / 2$ vs. K8/3, K12/2 vs. K12/3, K14/2 vs. $\mathrm{K} 14 / 3$ and $\mathrm{K} 15 / 2$ vs. K15/3 in group A). When comparing the K4/2 strip with its $\mathrm{K} 4 / 3$ counterpart, the faint anti-BZLF1 band seen at day 28 has changed into strong 


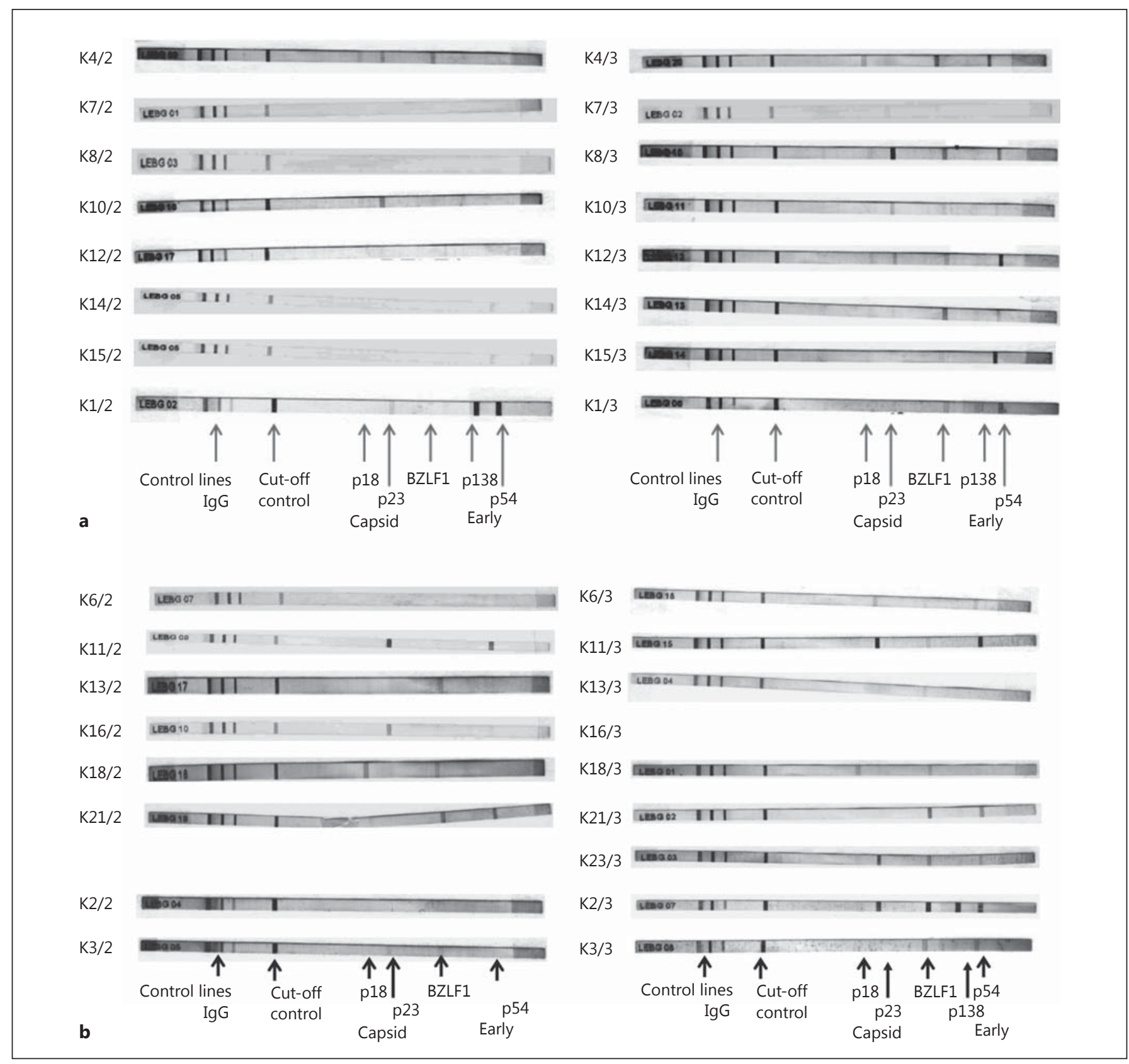

Fig. 3. IB technique depicts the serum antibody response against individual recombinant antigens p18, p23, BZLF1/Zta, p138 and p54 in group A rabbits (a) and group B animals (b) by day 28 (left) as well as on day 98 (right). See Results for details.

reaction, confirming increased reactivity of the corresponding antibody on day 98 . The well-defined strongly positive bands visible on day 28 might become faint at day 98 , as seen for example in the $\mathrm{K} 1 / 2$ versus $\mathrm{K} 1 / 3$ strips. When counting the frequency of individual bands, the positive rate of antibodies to BZLF1/Zta transactivator polypeptide was the highest (an average of $69.2 \%$ ), fol- lowed by anti-p54 (53.4\%) and finally by the anti-p23 antibodies, which revealed an average rate of $35.8 \%$ (fig. 4).

The serum reactivity against individual antigens as detected by IB test and ELISA (table 2) showed that among the group A rabbits (which received the lower virus dose), only 3 out of 10 serum samples (rabbits K7, K8 and N5) 
Table 3. Rabbit sera showing incoherent ELISA versus IB results*

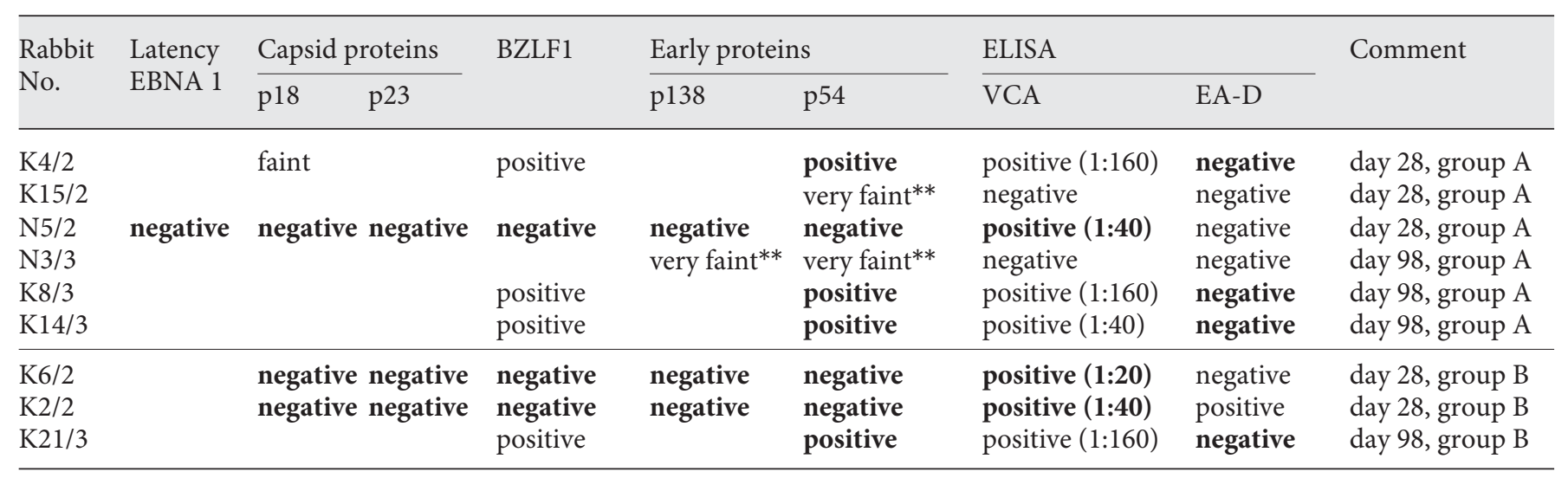

* Found in 9 out of 38 samples tested (23.6\%), discrepancies in bold. ** Probably non-specific bands, declared for negative.

were negative by ELISA on day 28 p.i. Several group A rabbits showed incoherent results (table 3 ), namely negative EA-D ELISA but positive VCA ELISA either on day 28 (2 animals) or on day 98 ( 5 animals). The serum of one of the former (rabbit No. K4/2) reacted with the p54 band and alternatively, two sera $(\mathrm{K} 8 / 3$ and $\mathrm{K} 14 / 3)$ coming from the latter interval (day 98) showed a similarly controversial antibody pattern (table 3 ). The number of negative rabbits decreased on day 98 , when a single rabbit $(\mathrm{N} 3 / 3)$, which had been negative by ELISA, revealed a very faint (probably non-specific) reaction by IB. On day 98 , the positive rate of antibodies reacting in IB test became higher as compared to day 28 . The majority of group A sera showed a more relevant correlation if comparing the results of the ELISA and IB tests. This was especially true for those samples, which were positive against both ELISA antigens (VCA as well as EA-D). It should be mentioned that no anti-EBNA1 antibody was seen in any of the serum samples examined by IB on days 28 and 98 p.i.

The sera of group $B$ animals (coming from rabbits inoculated with the higher EBV DNA dose), showed a better correlation between EA-D reaction and the p54 band as seen by IB results, since only one EA-D-negative serum sample (rabbit No. K21/3) reacted with the p54 band (compare tables 2 and 3 ). On the other hand, 2 serum samples which were negative by IB on day 28 , showed positive reaction with the capsid antigen in ELISA. The positive reaction to VCA might reflect a response to the virus administered in the absence of its replication. When an EAD-negative sample, which was positive for VCA, revealed antibodies in IB reacted not only with the 23 capsid polypeptide, but also with the BZLF1 transactivation protein,

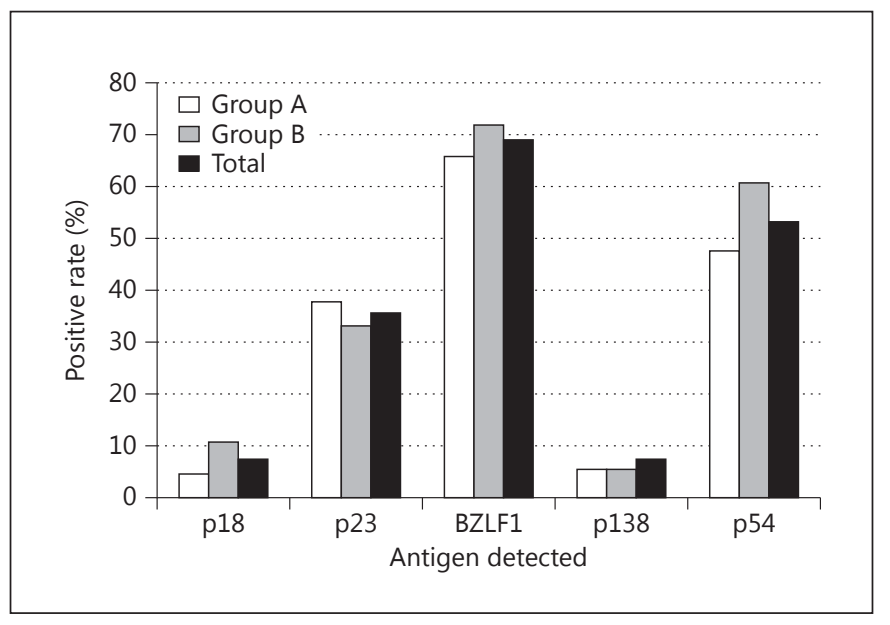

Fig. 4. Frequency of antibodies to p18, p23, BZLF1/Zta, p54 and p138 antigens (polypeptides) as detected by IB in both rabbit groups.

the corresponding animal might be regarded as infected. The antibodies to BZLF1 polypeptide were regarded as a sign of active (and/or recent) infection especially if they occurred along with antibodies to the early protein $\mathrm{p} 54$. The combination of both the positive BZLF1 as well as p54 reactions occurred in 6 out of 10 rabbits of group A (60\%) and in 6 out of 8 rabbits (75\%) of group B. This means that a total of 12 samples from 18 infected animals (i.e. 66\%) fulfilled the criterion for developing serological response proving acute or recent infection. 


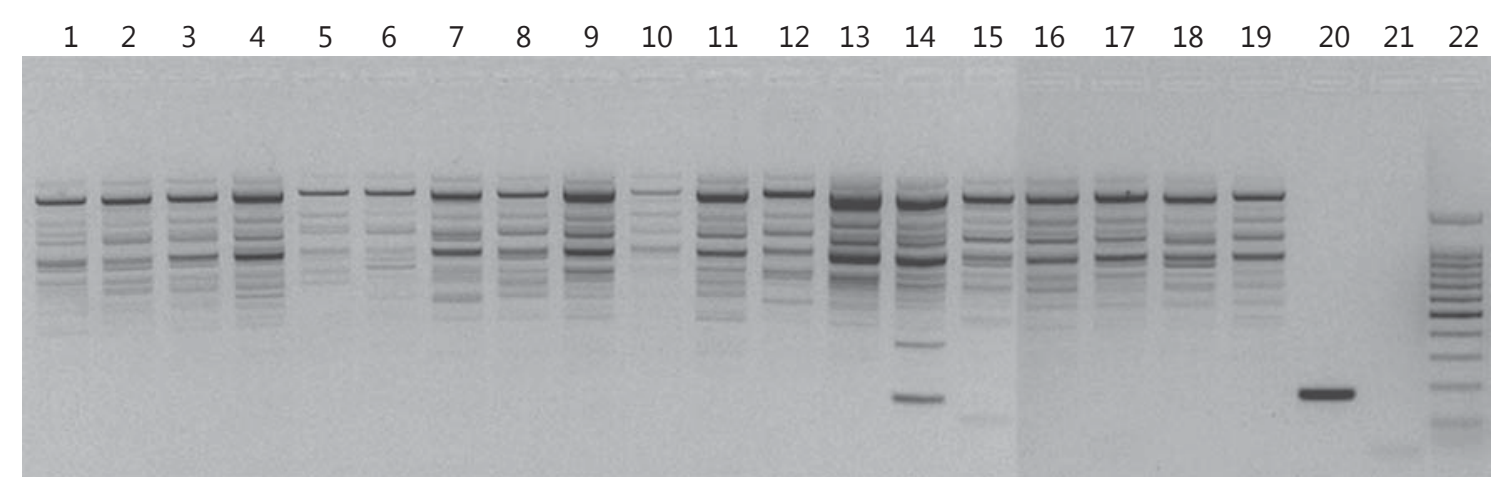

Fig. 5. Detection of EBV DNA by classical single-round PCR (LMP1 primers, 40 cycles) in the WBC extracts coming from day 8 p.i. (interval 1 ). Lanes: $1=\mathrm{K} 4 / 1 ; 2=\mathrm{K} 7 / 1 ; 3=\mathrm{K} 8 / 1 ; 4=\mathrm{K} 10 / 1$; $5=\mathrm{K} 12 / 1 ; 6=\mathrm{K} 14 / 1 ; 7=\mathrm{K} 15 / 1 ; 8=\mathrm{N} 3 / 1 ; 9=\mathrm{N} 5 / 1 ; 10=\mathrm{N} 6 / 1$;
$11=\mathrm{K} 6 / 1 ; 12=\mathrm{K} 9 / 1 ; 13=\mathrm{K} 11 / 1 ; 14=\mathrm{K} 13 / 1$ (positive) $; 15=\mathrm{K} 16 / 1$; $16=\mathrm{K} 18 / 1 ; 17=\mathrm{K} 21 / 1 ; 18=\mathrm{K} 23 / 1 ; 19=\mathrm{K} 1 / 1 ; 20=\mathrm{LCL} 721$ $1: 1,000$ (positive cell control); 21 = water (negative control); $22=$ markers from 100 to $1,200 \mathrm{bp}$.

\section{Comparing the EBV DNA versus LMP1 Antigen Detection}

Classical PCR and/or nested PCR were made with the WBC and spleen DNA extracts. On day 8, only 1 sample (K13/1) showed a specific band (line 14) with the same size of $187 \mathrm{bp}$ as the band (line 20) amplified from the EBV DNA-positive (control) cell extract (fig. 5). The positive as well as the uncertain sample bands were re-examined by nested PCR along with negative and positive controls. However, no additional positive bands appeared after nested PCR procedure. The WBC smears from EBV DNA-positive WBC samples were independently examined following indirect IF staining for LMP1 antigen (fig. 6). The IF of LMP1 antigen was identified as a ring-shaped rim on the surface of a few lymphocytes seen in the field of view from individual WBC smears. In 6 cases the IF results were in good agreement with the DNA presence as detected by PCR. Table 4 shows that EBV DNA was found at different post-infection intervals in 7 out of 21 animals only (30\%). The number of cases when a relatively satisfactory agreement was found between DNA presence and LMP1 detection in WBC specimens has increased slightly up to day 98 p.i. Particularly on day 8 the EBV DNA presence in WBC extracts correlated with the LMP1 antigen expression in 1 rabbit (K13), on day 28 in 2 rabbits (K1, K21), and on day 98 in 3 rabbits (K12, N5 and K2). The EBV DNA in WBCs as well as in spleen were positive at day 98 in rabbit No. K10. Furthermore, the DNA in WBCs and spleen as well as the LMP1 antigen in WBC smears were simultaneously found in 1 case at day 98 (rabbit No. K2). In 1 additional case (rabbit No. K18) the EBV DNA was found only. In 2 cases (rabbit Nos. K1 and K14), the LMP1 antigen was seen in lym-

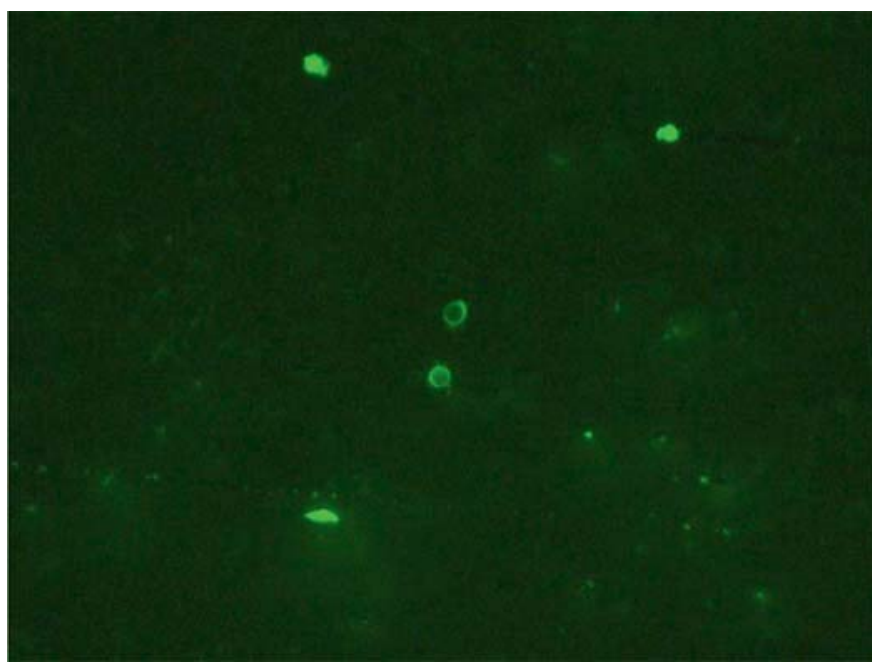

Fig. 6. Ring-shaped IF of LMP1 antigen (two lymphocytes) along with the non-specific staining of cell debris. $\times 600$.

phocytes of WBC smears but no corresponding DNA has been detected. If the positive IF was seen at single interval alone (rabbit No. K1), such a finding was not specifically regarded. As compared to the total sample number at each interval examined, the average positive rate of DNA detection in WBC extracts was considerably lower than the antibody-positive rate at given time intervals when it ranged from $5 \%$ (on day 8 p.i.) to $22 \%$ (on day 98 p.i.) only. We conclude that the positive rate of DNA detection in WBCs correlated with the LMP1 antigen expression in WBCs (fig. 7), but in a great proportion of seropositive cases, neither EBV DNA nor LMP1 antigen could be detected. 
Table 4. Comparison of EBV DNA and LMP1 antigen detection in EBV-infected rabbits

\begin{tabular}{|c|c|c|c|c|c|c|c|c|}
\hline Rabbit No. & $\begin{array}{l}\text { Day } 8 \\
\text { WBC/DNA }\end{array}$ & $\begin{array}{l}\text { Day } 28 \\
\text { WBC/DNA }\end{array}$ & $\begin{array}{l}\text { Day } 8 \\
\text { WBC/LMP1 }\end{array}$ & $\begin{array}{l}\text { Day } 28 \\
\text { WBC/LMP1 }\end{array}$ & \multicolumn{3}{|l|}{ Day 98} & Comment \\
\hline $\mathrm{K} 10^{\top}$ & negative & negative & negative & negative & negative & positive & positive & DNA only \\
\hline K12 & negative & negative & negative & negative & positive & positive & negative & agreement 1 \\
\hline K14 & negative & negative & positive* & positive* & negative & negative & negative & *no DNA \\
\hline \multicolumn{9}{|c|}{ Group B rabbits } \\
\hline $\mathrm{K} 13$ & positive & negative & positive & negative & negative & negative & negative & agreement 3 \\
\hline K21 & negative & positive & negative & positive & negative & negative & negative & agreement 4 \\
\hline K2 & negative & negative & negative & negative & positive & positive & positive & agreement 5 \\
\hline K3 & negative & positive & negative & positive & negative & negative & negative & agreement 6 \\
\hline
\end{tabular}

* No DNA was found.

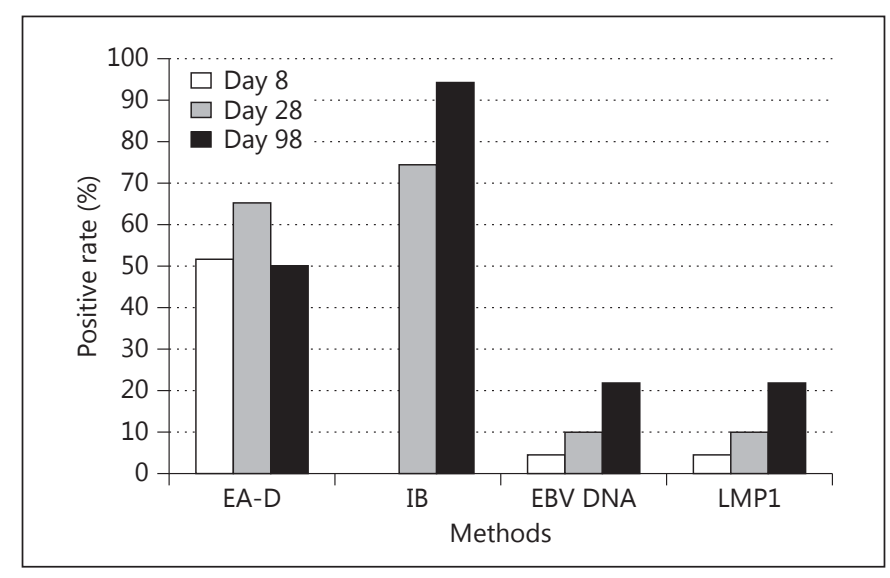

Fig. 7. Overall frequency of DNA expression in WBCs was considerably lower than the serology-positive rates. As compared to DNA detection, the LMP1 antigen was expressed in WBCs at a similar frequency. With exception of EA-D serology, the positive rates by all other three methods were the highest on day 98 p.i. Since the IB serology was not done on day 8 p.i., the corresponding data are missing. The EA-D antibody-positive rates at 98 day were lower as compared to the frequency of antibodies detected by IB, but the averages of both showed no significant difference $(\mathrm{p}=0.417941)$. In contrast, the EBV DNA and LMP1-positive rates were considerably lower than the serology-positive rates $(\mathrm{EA}-\mathrm{D}$ to DNA/LMP1 differ at $\mathrm{p}=0.012931$;B to DNA/LMP1 differ at $\mathrm{p}=0.005433$, respectively). The positive rates of the DNA and LMP1 are in good correlation to each other.

\section{Staining of Whole Blood Smears}

Whole blood smears were viewed and counted for relative proportion of lymphocytes and macrophages versus atypical mononuclear cells. No typical infectious mono- nucleosis-like syndrome was seen, though the proportion of cases in which a relative increase of lymphocytes (over $60 \%$ ) had been found exceeded $50 \%$ on day 8 and peaked on day 28 p.i. Alternatively, the proportion of rabbits with increased relative number of atypical mononuclear cells in blood smears (slightly over 10\%) was the highest on day 8 , when it reached $36 \%$ of animals. As shown in table 5 , the number of rabbits in which lymphocytosis developed was close to the frequency of positive EA-D antibodies. The proportion of animals which had atypical mononuclear cells in their blood smears peaked on day 8 . Their positive rate was considerably lower than the frequency of those which revealed lymphocytosis. At the earlier intervals there was no clear correlation between the occurrence of LMP1-expressing lymphocytes and the presence of atypical cells. Only on day 98 the slightly increasing frequency of LMP1-expressing lymphocytes became nearly as frequent as the proportion of animals revealing a significant increase of atypical mononuclear cells.

\section{Discussion}

\section{Analysis of Serological Results}

The interpretation of antibody formation against capsid antigen (VCA) as detected by ELISA was difficult in group B serum samples, which showed a positive reaction already before EBV infection (interval 0 ) at the dilution of 1:20 recommended by the manufacturer. According to the presence and/or absence of elevated back- 
Table 5. Proportion of rabbits exhibiting lymphocytosis and atypical mononuclear cells (MCs) in peripheral blood smears as compared to DNA and LMP1 tests

\begin{tabular}{lcll}
\hline Test & Day 8 & Day 28 & Day 98 \\
\hline WBC/DNA & $5 \%$ & $10 \%$ & $22 \%$ \\
WBC/LMP1 & $5 \%$ & $10 \%$ & $22 \%$ \\
WBC/atypical MCs* & $35.7 \%$ & $29.4 \%$ & $23.5 \%$ \\
WBC/lymphocytosis** & $57.1 \%$ & $66.6 \%$ & $35.3 \%$ \\
EA-D ELISA & $52.0 \%$ & $65.0 \%$ & $50.0 \%$ \\
\hline
\end{tabular}

* Atypical MCs slightly over 10\%. ** Lymphocytes over $60 \%$.

ground level of binding of the pre-infection serum samples, the rabbits were divided into two groups designated $A$ and $B$. To eliminate any interpretation problems associated with the elevated background binding of certain serum samples to the VCA-coated microplates, we examined all the serum samples at increasing dilutions to determine the final dilution still revealing a positive ISR value. In contrast to the capsid antigen, the EA-D microplates showed no non-specific binding at the interval before EBV administration. While in response to the lower virus dose no EA-D antibodies were found on day 8 by ELISA, after the higher EBV dose, this antibody has appeared in $58 \%$ of group B rabbits. The EA-D ELISApositive rate was in good correlation to the virus dose administered, since the group B sera showed more frequent and higher ISR values. For this reason we believe that the EA-D ELISA antibodies can better reflect the acute replication of inoculated virus in the lymphatic cells of infected animals than the VCA antibodies. This is in accord with the results of others showing that antiEA-D antibodies can be correctly identified in nearly $90 \%$ of acute, recent and/or past EBV infections. As repeatedly confirmed in laboratory routine, EA-D ELISA can be helpful in diagnosing immunocompetent patients with an isolated VCA IgG pattern [19] and/or in getting a precise diagnosis more reliable than testing the VCA IgM ELISA [20]. We compared the EA-D ELISA results with the occurrence of the p54 and BZLF1 bands as detected by IB. Among group A sera the presence of the p54 band (a virus-specific DNA polymerase cofactor encoded by the BMRF1 gene) was found in the absence of EA-D antibody in one serum on day 28 , and in an additional two by day 98 p.i. These observations probably reflect the higher sensitivity of the IB test (table 3). The coincident group A sera showed antibodies to the p54 early protein in 9 of 20 samples (45\%), while the BZLF1/ Zta transactivation protein was detected in 12 out of 20 rabbits (60\%). In the group B animals, the proportion of p54-positive sera was slightly higher, since it counted 11 samples out of $18(61 \%)$. Alternatively, the frequency of sera reactive with the BZLF1 polypeptide was 14 out of the 18 samples tested $(77.7 \%)$.

The different intensity of individual bands as seen in the IB strips (fig. 3a, b) could reflect the different binding capacity of antibodies directed against individual EBV proteins. This interpretation is based on the recommendations for scoring of the increased binding of antibodies provided by the manufacturer in order to differentiate between acute, recent and past infections $[16,21]$. Whenever required, the IB technique allows precise quantification when determining the affinity of binding [22]. It may be mentioned that the IB-based avidity testing as a confirmatory method of choice should be based on the change from an earlier faint to later more intensive staining as documented in some of our paired strips (fig. 3a, b). Under given conditions, it was possible to differentiate between acute and past EBV infections as described by others $[23,24]$. However, the differences seen in another two of our strip pairs (K14/2 and K14/3; K15/2 and $\mathrm{K} 15 / 3$ ), might be related to variations in the intensity of visualization reaction reflected by the cut-off bands. Furthermore, when the negative IB staining at earlier interval (day 28) became strongly positive within 2 months (day 98), this change might be simply related to an increased quantity of the specific IgG molecules present in blood plasma.

The BZLF1/Zta band as detected by IB points at the synthesis of Zta transactivator protein in infected rabbit tissues thus indicates either the activation of lytic virus replication and/or the initiation of early protein synthesis [25]. The BZLF1 protein along with the BRLF1 immediate early protein functions in accord as transcription factors activating other (early and late) EBV genes [26]. The BZLF1 protein belongs to the family of transcription factors possessing a DNA-binding domain homologous to $c$-jun and $c$-fos, which interacts with AP-1 consensus promoter designated ZRE (Z-responsive elements). Several data suggest that the $Z$ ta protein binds to an atypical AP-1 site of the BRLF1 promoter, and as a rule, both Zta as well as Rta are needed for efficient activation of lytic EBV genes. The BZLF1 protein was shown to bind also to the methylated sites of ZREII and to a recently recognized ZREIII motif within the BRLF1/Rp promoter, revealing a novel mechanism how the conventional blockade of the EBV genome may be overcome by 
the IE transactivator protein encoded by another virus [27]. In addition, the BZLF1 protein plays an important role in attenuating the host immune response by inhibiting TNF- $\alpha$ and abrogating IFN- $\gamma$ signaling [28]. In our rabbits, antibodies to BZLF1 were detected together in $69.2 \%$ of the serum samples examined by the IB technique. The presence of the BZLF1/Zta band in combination with the p54 antibodies doubtlessly indicates the initiation of EBV genome replication regardless of whether in nasopharyngeal epithelium cells (lytic replication) and/or in lymphatic tissues where restricted or abortive infection develops. When counting the proportion of double antibody-positive rabbits (not the positive sample rates), the above-mentioned combination of antibodies was seen in 6 out of 10 rabbits of group A (60\%) and alternatively in 6 out of 8 animals $(75 \%)$ of group B (a total of $66 \%$ ).

\section{Our Rabbit Model versus Human EBV Infection}

No infectious mononucleosis-like syndrome, so much typical for a proportion of human EBV infections [20], was seen in any of the infected rabbits, though a considerable number of animals had shown lymphocytosis and increased borderline values of atypical blood cells in their blood smears. As a rule, the first EBNA1 antibodies in humans may be found by 3 months (12 weeks) after the onset of disease $[17,23]$, i.e. about 16-17 weeks p.i. During acute disease, the EBNA-1 IgG is completely absent at least until 3-4 weeks after the onset of clinical symptoms [29]. In additional rabbit experiments not reported here, we found a clear absence of EBNA1 antibody even at the 116-day interval (i.e. by 16 weeks) post-infection. The missing EBNA1 bands in the IB strips at latter interval contrasted with the presence of intensive p54 and p23 bands (not shown). Okuno et al. [14], whose results are analyzed in more detail below, found no EBNA-IgG antibodies by ELISA in sera of their rabbits during an observation period over 200 days p.i. We assume that no typical latency type I as characterized by the presence of EBNA1 protein has developed in EBV-infected rabbits. EBNA-1 is a DNA-binding protein required for the replication and maintenance of the episomal EBV DNA and for its partition into dividing cells [30,31]. In the absence of EBNA1 polypeptide, the EBV genome might be easily eliminated from the infected $B$ cells. The latter function is associated with the binding of EBNA1 to cellular EPB2, which interacts with metaphase chromosomes [32]. The constitutive expression of EBNA1 in certain human Bcell lines can be explained by epigenetic differences between the degree of methylation of the silenced Wp and
Cp promoters and of the alternative downstream Qp promoter, which governs the EBNA1 mRNA transcription [33-35]. The Qp promoter in such lines is regulated by a repressor protein, which binds to the origin of circularized EBV plasmid replication and by feedback mechanism functions as an inhibitor of its own transcription $[33,36]$.

\section{Comparison of Rabbit Models for EBV Infection}

As Okuno et al. [14] described, the EBV antibody levels revealed significant increases in 4 EBV-DNA-positive rabbits (designated $\mathrm{OK} 4, \mathrm{OK} 5, \mathrm{OK} 8$, and $\mathrm{OK} 10$ ), but no significant elevation of EBV antibodies was found in other EBV-DNA-negative rabbits (the remaining 6 out of 10). Contrary to their report, we found a positive serologic response (as detected by three different tests) in relatively more rabbits than in which the EBV genome could be detected (either in WBCs and/or spleen). Furthermore, we did not observe the rare pattern of continuous DNA detection which had been described in 1 of 10 of their EBV-infected rabbits. In our hands, the DNA presence as detected by PCR in 7 out of 21 animals (30\%) was rather transient. This finding, however, does not contradict to that of intermittent mRNA transcription as described by Okuno et al. [14], who found EBNA1, EBNA2, and BZLF1 transcripts in some of their animals. For example in rabbit No. 4, the above-mentioned transcripts were intermittently detected from day 7 to day 249 p.i., while in rabbit No. 5 the EBNA2 transcript was found on day 14 only, while the BZLF1 mRNA was expressed on days 14 and 21. In rabbit Nos. OK8 and OK10, only the BZLF1 mRNA was detected on day 14 . In our hands, as mentioned, the occurrence of EBV DNA in peripheral blood leukocytes was rather transient. In 6 of the occasional EBV DNA carriers, also the LMP1 protein appeared (as detected by IF) at the same matching intervals (table 4). Since the purpose of our model was not to develop a lifelong EBV persistence, we did not search for EBV DNA at late intervals such as days 1,400 and 1,522 [36]. The EBV DNA persistence in the spleen as revealed by the presence of EBER-positive lymphocytes, LMP1, EBNA2 and ZEBRA mRNAs occurred in a proportion of rabbits resulting from intravenous inoculation with a very high virus load [13]. It seems that both the route of virus administration as well as the source of the inoculated virus might be essential for its further spread and for the efficiency of elimination of the persisting (or latent) virus genome [38-40]. Summing up, the EBV DNA in our rabbits was present in a smaller proportion of B lymphocytes along with si- 
multaneous expression of LMP1 antigen and the absence of EBNA-1 antibody. Our rabbits did not develop a typical infectious mononucleosis-like syndrome. Just a mild increase in the number of atypical mononuclear cells and an increased proportion of lymphocytes could be found in blood smears. The frequency of these atypical WBCs was rather related to the frequency of EA-D antibodies than to LMP1 antigen expression (table 5). Our experiments in a relatively representative number of rabbits infected with two slightly different EBV doses prompted the idea to select reliable and simple techniques suitable for large-scale animal studies for the in vivo the efficacy of the EBV epitopes (according to fig. 7). However, further studies are needed to confirm or refute the absence of EBNA1 transcripts and/or of EBNA1 protein in EBV-infected rabbits.

\section{Acknowledgements}

This work was sponsored by a grant from the Hungarian National Development Agency Development of new EBV vaccines for therapeutic applications (registration No. TECH-08-A1/22008-01-08). The authors thank Dr. J. Minarovits, ScD, from the Department of Oral Biology and Experimental Dental Research, Faculty of Dentistry, University of Szeged, Hungary, for his kind remarks and useful suggestions.

\section{References}

$\checkmark 1$ Hayashi K, Teramoto N, Akagi T: Animal in vivo models of EBV-associated lymphoproliferative diseases: special reference to rabbit models. Histol Histopathol 2002;17:1293-1310.

-2 Ferrari MG, Rivadeneira ED, Jarrett R, Stevceva L, Takemoto S, Markham P, Franchini G: $\mathrm{HV}(\mathrm{MNE})$ a novel lymphocryptovirus related to Epstein-Barr virus, induces lymphoma in New Zealand white rabbits. Blood 2001;8: 2193-2199.

$>3$ Hayashi K, Chen HL, Yanai H, Koirala TR, Ohara N, Teramoto N, Oka T, Yoshino T, Takahashi K, Miyamoto K, Fujimoto K, Yoshikawa Y, Akagi T: Cyno-EBV (EBV-related herpesvirus from cynomolgus macaques) induces rabbit malignant lymphomas and their tumor cell lines frequently show specific chromosomal abnormalities. Lab Invest 1999; 79:823-835.

4 Hayashi K, Ohara N, Teramoto N, Onoda S, Chen HL, Oka T, Kondo E, Yoshino T, Takahashi K, Yates J, Akagi T: An animal model for human EBV-associated hemophagic syndrome: Herpesvirus papio frequently induces fatal lymphoproliferative disorders with hemocytophagic syndrome in rabbits. Am J Pathol 2001;158:1533-1542.

$>5$ Hayashi K, Jin Z, Onoda S, Joko H, Teramoto N, Ohara N, Oda W, Tanaka T, Liu YX, Koirala TR, Oka T, Kondo E, Yoshino T, Takahashi K, Akagi T: Rabbit model for human EBV-associated hemophagocytic syndrome: sequential autopsy analysis and characterization of IL-2-dependent cell lines established from herpesvirus papio-induced fatal rabbit lymphoproliferative diseases with HPS. Am J Pathol 2003;162:1721-1736.

6 Wutzler P, Meerbach A, Färber I, Wolf H, Scheibner K: Malignant lymphomas induced by an Epstein-Barr virus-related herpesvirus from Macaca arctoides - a rabbit model. Arch Virol 1995;140:1979-1995.
7 Nash AA, Dutia BM, Stewart JP, Davison AJ: Natural history of murine gammaherpesvirus infection. Philos Trans R Soc Lond B Biol Sci 2001;356:569-579.

8 Rajćáni J, Kúdelová M: Murine herpesvirus pathogenesis: a model for the analysis of molecular mechanisms of human herpesvirus infections. Acta Microbiol Immunol 2005;52: 41-71.

$>9$ Rajčáni J, Kúdelová M: Murid herpesvirus 4 (MuHV-4): an animal model for human gammaherpesvirus research; in Minarovits J, Gonczol E, Valyi-Nagy T (eds): Latency Strategies of Herpesviruses. New York, Springer, 2006, chapt 5, pp 102-136.

$>10$ Stevenson PG, Simas JP, Efstathiou S, Immune control of mammalian gammaherpesviruses: lessons from murid herpesvirus 4 . J Gen Virol 2009;90:2317-2330.

11 Cocco M, Bellan C, Tussiwand R, Corti D, Traggiai E, Lazzi S, Mannucci S, Bronz L, Palummo N, Ginanneschi C, Tosi P, Lanzavecchia A, Manz MG, Leoncini L: CD34 cord blood-transplanted Rag2-/- $\gamma_{c}-/-$ mice as a model for Epstein-Barr virus infection. Am J Pathol 2009;173:1369-1378.

12 Castiglione F, Duca K, Jarrah A, Laubenbacher R, Hochberg D, Thorley-Lawson D: Simulating Epstein-Barr virus infection with CImmSim. Bioinformatics 2007;23:1371-1377.

13 Takashima K, Ohashi M, Kitamura Y, Ando K, Nagashima K, Sugihara H, Okuno K, Sairenji T, Hayashi K: A new animal model for primary and persistent Epstein-Barr virus infection: human EBV-infected rabbit characteristics determined using sequential imaging and pathological analysis. J Med Virol 2008;80:455-466.
14 Okuno K, Takashima K, Kanai K, Ohashi M, Hyuga R, Sugihara H, Kuwamoto S, Kato M, Sano H, Sairenji T, Kanzaki S, Hayashi K: Epstein-Barr virus can infect rabbits by the intranasal and preoral route: an animal model for natural primary EBV infection in humans. J Med Virol 2010;82:977-986.

15 Färber I, Hinderer W, Rothe M, Lang D, Sonneborn HH, Wutzler P: Serological diagnosis of Epstein-Barr virus infection by novel ELISAs based on recombinant capsid antigens p23 and p18. J Med Virol 2001;63:271-276.

16 Microgen Line Assay: Determination of the avidity of anti-EBV-IgG against single antigens. Internal Notice Bauer 2003.

17 Moss DJ, Burrows SR, Khanina R: EBV: immunobiology and host response; in Arvin A, Campadelli-Fiume G, Mocarski E, Moore PS, Roizman B, Whitley R, Yamanishi K (eds): Human Herpesviruses, Biology, Therapy and Immunoprophylaxis. Cambridge, Cambridge University Press, 2007, pp 904-914.

18 Baer R, Bankier AT, Biggin MD, Deininger PL, Farrell PJ, Gibson TJ, Hatfull G, Hudson GS, Satchwell SC, Séguin C, Tuffnell PS, Barrell BG: DNA sequence and expression of the B95-8 Epstein-Barr virus genome. Nature 1984;310:207-211.

19 De Paschale M, Cagnin D, Cerulli T, Manco MT, Agrappi C, Mirri P, Gatti A, Rescaldani C, Clerici P: Search for anti-EA $A_{D}$ antibodies in subjects with an isolated VCA IgG pattern. Int J Microbiol 2010;24:50-52.

20 Ambinder R, Cesarman E: Clinical and pathological aspects of EBV and KSHV infection; in Arvin A, Campadelli Fiume G, Mocarski E, Moore PS, Roizman B, Whitley R, Yamanishi K (eds): Human Herpesviruses, Biology, Therapy and Immunoprophylaxis. Cambridge, Cambridge University Press, 2007, pp 885-903. 
-21 Klutts JS, Ford BA, Perez NR, Gronowski AM: Evidence-based approach for interpretation of Epstein-Barr virus serological patterns. J Clin Microbiol 2009;47:3204-3210.

22 Bauer G: Simplicity through complexity: immunoblot with recombinant antigens as the new gold standard in Epstein-Barr virus serology. Clin Lab 2001;47:223-230.

23 De Paschale M, Clerici P: Serological diagnosis of EBV infection: problems and solutions. World J Virol 2012;11:31-43.

24 Schubert J, Zens W, Weissbrich W: Comparative evaluation of the use of immunoblots and of IgG avidity assays as confirmatory tests for the diagnosis of acute EBV infections. J Clin Virol 1998;11:161-172.

25 Kenney SC: Reactivation and lytic replication of EBV; in Arvin A, Campadelli-Fiume G, Mocarski E, Moore PS, Roizman B, Whitley R, Yamanishi K (eds): Human Herpesviruses, Biology, Therapy and Immunoprophylaxis. Cambridge, Cambridge University Press, 2007, pp 403-443.

26 Feederle R, Kost M, Baumann M, Janz A, Drouet E, Hammerschmidt W, Delecluse HJ The Epstein-Barr virus lytic program is controlled by the cooperative functions of two transactivators. EMBO J 2000;9:3080-3089.

27 Bhende PM, Seaman VT, Delecluse HJ, Kenney SC: The EBV lytic protein Z preferentially binds to and activates the methylated viral genome. Nat Genet 2004;6:1099-1014.
28 Morrison TE, Mauser A, Wong A, Ting JP, Kenney SC: Inhibition of IFN-a signaling by an Epstein-Barr virus immediate early protein. Immunity 2001;15:787-799.

29 Schillinger M, Kampmann M, Henninger K, Murray G, Hanseknabb I, Bauer G: Variability of humoral immune response in acute Epstein-Barr virus infection: evaluation of the significance of serological markers. Med Microbiol Lett 1993;2:296-303.

30 Leight ER, Sugden B: EBNA1: a protein pivotal to latent infection by Epstein-Barr virus. Rev Med Virol 2000;10:83-100.

31 Westhoff-Smith D, Sugden B: Potential cellular functions of Epstein-Barr nuclear antigen 1 (EBNA1) of Epstein-Barr virus. Viruses 2013;5:226-240.

$32 \mathrm{Wu} \mathrm{H}$, Cecarelli DF, Frappier L: The DNA segregation mechanism of Epstein-Barr virus nuclear antigen 1. EMBO 2000;1:140-144.

33 Minarovits J: Epigenotypes of latent herpesvirus genomes. Curr Top Microbiol Immunol 2006;310:61-80.

34 Sivachandran N, Wang X, Frappier L: Functions of the Epstein-Barr virus EBNA1 protein in viral reactivation and lytic infection. J Virol 2012;86:6146-6158.

35 Takacs M, Banati F, Koroknai A, Segesdi J, Salamon D, Wolf H, Niller HH, Minarovits J: Epigenetic regulation of latent Epstein-Barr virus promoters. Biochem Biophys Acta 2010; 1799:228-235.
36 Sample J, Henson EB, Sample C: The EpsteinBarr virus nuclear protein-1 promoter active in type I latency is autoregulated. J Virol 1992; 66:4654-4661.

37 Kanai K, Takashima K, Okuno K, Kato K, Sano H, Kuwamoto S, Higaki H, Nagata K, Sugihara H, Kato M, Murakami I, Hayashi K: Lifelong persistent infection of rabbits with EBER-1-positive lymphocyte infiltration and mild sublethal hemophagocytosis. Virus Res 2010;153:172-178.

38 Kalla M, Hammerschmidt W: Human B cells on their route to latent infection - early but transient expression of the lytic genes of Epstein-Barr virus. Eur J Cell Biol 2012;91:6569.

39 Young LS, Arrand JR, Murray PG: EBV gene expression and replication; in Arvin A, Campadelli-Fiume G, Mocarski E, Moore PS, Roizman B, Whitley R, Yamanishi K, (eds): Human Herpesviruses, Biology, Therapy and Immunoprophylaxis. Cambridge, Cambridge University Press, 2007, pp 461-489.

40 Sano H, Nagata K, Kato K, Kanai K, Yamamoto K, Okuno K, Kuwamoto S, Higaki-Mori H, Sugihara H, Kato M, Murakami I, Kanzaki S, Hayashi K: EBNA-2 deleted EpsteinBarr virus from P3HR-1 can infect rabbits with lower efficiency than prototype EpsteinBarr virus genome B95-8. Intervirology 2013; 56:114-121. 